\title{
The causality between economic growth, poverty, and stunting: empirical evidence from Indonesia
}

\author{
Dwi Darma Puspita Sari; Taufiq Marwa; Sukanto*; Abdul Bashir \\ Department of Development Economics, Faculty of Economics, Universitas Sriwijaya, \\ Indonesia \\ *To whom correspondence should be addressed.Email: soekanto0813@fe.unsri.ac.id

\begin{tabular}{|l|l|l|l|l|}
\hline DOI: & Received: & Revised: & Accepted: & Published: \\
$10.22437 /$ ppd.v8i1.8834 & 06.03 .2020 & 09.04 .2020 & 10.04 .2020 & 30.04 .2020 \\
\hline
\end{tabular}

\begin{abstract}
This study investigate the relationship between economic growth, poverty, and stunting in Indonesia. Observation during 2015-2017 in 34 regions in Indonesia. Using a spatial approach with Klassen's typology and applying the panel vector error correction model. The finding indicated that the priority handling of the problem of the high stunting prevalence focuses on the islands of Sulawesi, Maluku, Kalimantan, Nusa Tenggara, and Papua. Furthermore, addressing the problem of economic growth slows focuses on the Islands of Kalimantan and Sumatra. Meanwhile, the handling of high poverty levels focuses on the islands of Sulawesi, Sumatra, Nusa Tenggara, Maluku, and Papua. On the other side of this study, we get evidence of unidirectional causality flowing from poverty rates and the stunting prevalence toward economic growth in the long-run. The contribution of the stunting case is more dominant to have an impact on slowing economic growth. We also find evidence of unidirectional causality flowing from economic growth and stunting to poverty levels in the long-run, the contribution of economic growth is relatively more dominant with an impact on reducing poverty levels. While there is no evidence of causality flowing from economic growth and poverty to stunting, we have also found that poverty rates have a relatively high contribution to the increase in stunting cases in Indonesia.
\end{abstract}

Keywords: Causality, Economic growth, Poverty, Stunting

JEL Classification: $\mathrm{O} 15, \mathrm{P} 36$

\section{INTRODUCTION}

Stunting has become a major challenge for developing countries recently. Report released by the World Health Organization (2018) recommended that the upper-middleincome countries to reduce the rate of stunting by as much as 64 percent. Meanwhile, the middle-income countries are suggested to reduce the rate of stunting by 24 percent during the year 2000 to 2017 . The issue of stunting is currently a fierce debate in the literature about whether economic growth has made a major contribution to reducing child stunting (Alderman, Haddad, \& Headey, 2014; Mary, 2018; Ruel \& Alderman, 2013; and Smith \& Haddad, 2015). This debate has major policy implications for the relative role given to pro-poor growth strategy to reduce children malnutrition and the need for direct 
complementary nutritional investment as an extension to influence how limited financial resources are allocated competitively among various types of investments. Given the lack of consensus on this debate and the importance of the policy, this study reviews the relationship between economic growth and children stunting.

On the other side, stunting can have negative impact on economic growth (Mary, 2018; and Onis \& Branca, 2016). Gross domestic product of Indonesia experienced 2-3 percent losses due to stunting. Indonesia is ranked fifth among countries with the highest stunting burden on children under five, with more than 7.6 million children in sub-optimal body growth (Titaley, Ariawan, Hapsari, Muasyaroh, \& Dibley, 2019), Moreover, one third of children under age five experience body growth that did not meet the international height standard (World Health Organization, 2018). Empirical study conducted by Barker (2007) found that the problem of stunting, fat, and non-communicable diseases originated from the process of fetal growth and development in the womb until the age of two. Furthermore, malnutrition can lead to disruption of growth in children, resulting in abnormalities in body shape, even though gene factors in the cells indicate the potential for normal child body.

Stunting is called a short toddlers, which becomes one of the problems of malnutrition experienced by toddlers (Vonaesch et al., 2017). In 2017, 22.2 percent arround 150.8 million children under five were stunted. Nevertheless, the figure has decrease compared to 2000 which reached 32.6 percent. In 2017, stunting was experienced by more than half of Asian toddler, while a third experienced by toddlers in Africa. Toddlers in Asia who suffered stunting as much as 83.6 million toddlers in Asia were stunted, where the proportion of stunting case mostly found in South Asia at 58.7 percent, and the least are in Central Asia at 0.9 percent (World Health Organization, 2018).

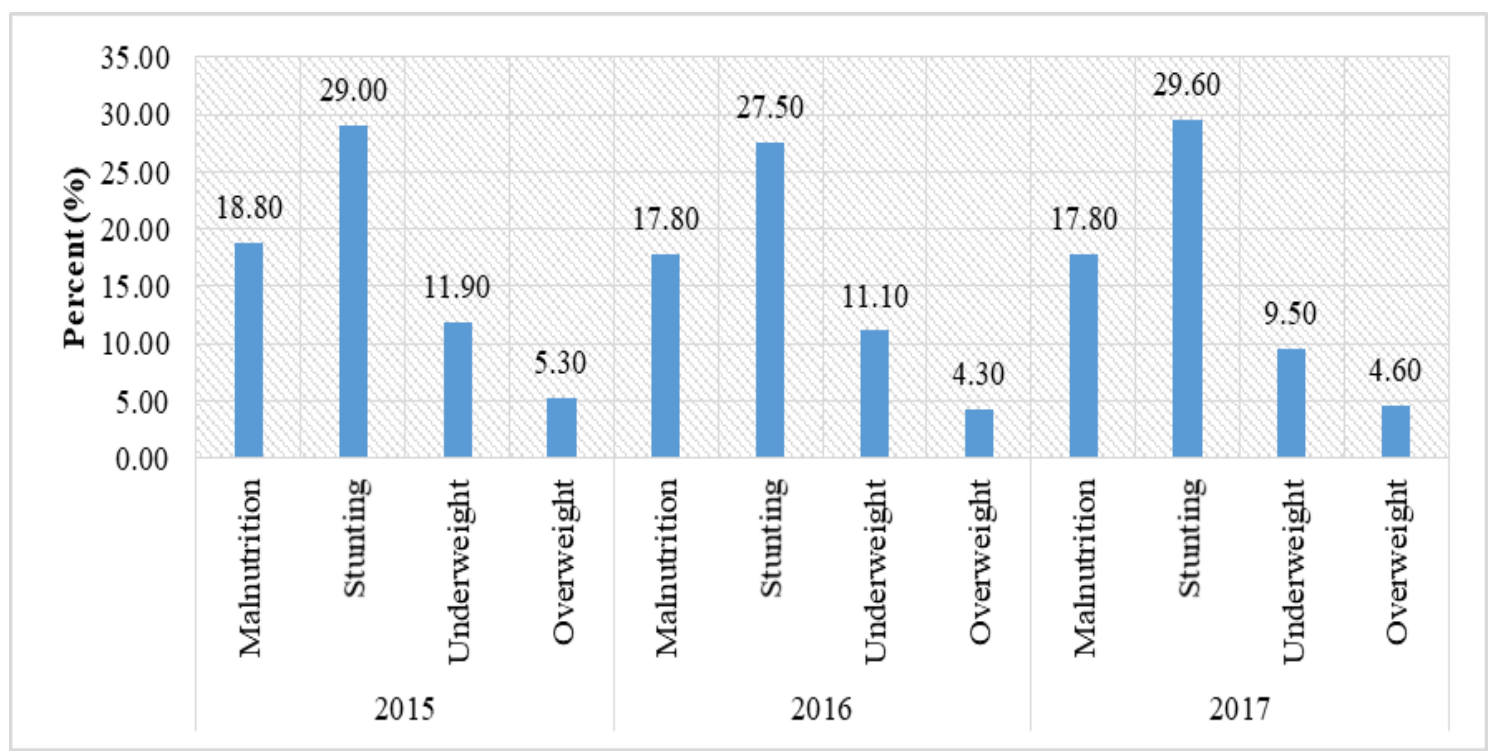

Figure 1. Nutrition Problems in Indonesia, 2015-2017

Source: Nutritional Status Monitoring, Directorate General of Public Health

There are several factors that can affect the nutritional problems in children directly or indirectly. In general, the roots of this problems are economic status or family income which can affect toddlers' nutrition (Semba \& Bloem, 2001). The imbalance consumption of nutritious foods can provide an indication of malnutrition, which is associated with 
poverty. The prevalence of toddler malnutrition in Indonesia reached 19.6 percent, which means toddler malnutrition is still a major problem in the health sector as it approaches the high prevalence. Sustainable Development Goals (SDGs) target in 2019 is 28 percent and becomes a challenge for Indonesia. In general, nutritional problems in Indonesia are caused by a lack of consuming food that contains protein and energy. Nutritional Status Monitoring (PSG) noted that the prevalence of toddler stunting in 2017 is at $29.6 \%$, higher than 2016 at $27.5 \%$ (Figure 1). The increase in stunting is due to ecological problems, with the interaction of various environmental factors, both physical, social, economic, cultural, and political (Onis \& Branca, 2016). Operationally, the triggering factors for the emergence of malnutrition problems are mother's nutrition knowledge, income, lifestyle, and environment.

Children who suffer from stunting can experience Intelligence Quotient (IQ) disorder. Children who suffer from severe malnutrition or stunting has IQ score that 11 points lower than children who are not suffer from stunting. On the other hand, stunting can also lead to degenerative diseases such as underweight (Vilcins, Sly, \& Jagals, 2018). Longitudinal studies in children in Brazil, Guatemala, India, Philippines, and South Africa about the reduction in schooling showed that children affected by stunting in the age of two will experience a delay in completing the school for approximately one year (Adair et al., 2013; Martorell et al., 2010). Some of the malnutrition problems such as underweight, stunted, and wasted can be solved from the nutritional ecology approach, namely: (1) access to clean water and health services; (2) economic and social assets as a reflection of socio-economic access to food; and (3) malnutrition (Crahay et al., 2010).

Related literature in this study as (Adeyeye, Adebayo-Oyetoro, \& Tiamiyu, 2017) found that low agricultural productivity, and lost of harvest production can cause a lack of important nutritional food. Low education level can be a major factor in malnutrition, and the climate changes can have an impact on food production, causing various diseases such as diarrhea and malnutrition. Another study conducted by Larrea \& Kawach (2005) proved that economic inequalities can be the deciding factor of population health level and it also showed that there is a relationship between economic inequality and child malnutrition. In addition, study conducted by Kuada (2014) showed that the increase in spending on health in developing countries can increase the value of productivity and social benefits. The benefits also had some impacts on the improvement of child health care. The study also proved that there is a relationship between health spending and the improvement of children's health and nutrition.

Study conducted by Jr Richard (2004) shows that economic growth can reduce poverty, and poverty is highly dependent on economic growth. When economic growth is measured in terms of income (consumption), it shows that there is a relationship between economic growth and poverty. Further studies conducted by Mcgovern, Krishna, Aguayo, \& Subramanian (2017) showed that the economic growth led to a decrease of stunting, despite having a relatively small relationship. Differently, Frimpong, Okoye, \& Pongou (2016) stated that the prevalence of stunting increased along with the increase of economic growth. Other than that, Frimpong, Okoye, \& Pongou. (2016) stated that economic growth in developing countries will cause the increased in stunting and poverty.

Another study conducted by Rashad \& Sharaf (2018) found that as a whole, economic growth is regarded as an effective instrument to fight poverty and children malnutrition. By sector, according to Mary (2018) it is proved that economic growth in the agricultural sector is more effective in reducing stunting than non-agricultural ones. 
The study was also carried out by Ogundari \& Aromolaran (2017) which proves that a positive growth rate in the agricultural sector led to a reduction of poverty and stunting. The study was also supported by Lyakurwa (2009); Ogundari \& Aromolaran (2017); Pulok, Sabah, \& Enemark (2016); and Vollmer et al. (2014) which proves that the growth of all sectors of the economy has a significant effect on reducing poverty and stunting. The differences among previous studies is still a debate among experts. It is important to confirm the differences among those studies, especially in Indonesia. Therefore, the objectives of this study to investigate the relationship between economic growth, poverty rate, and stunting in Indonesia. Contributions from the study results may provide policy recommendations to the reduction of poverty and stunting and being appealing literature in the development of science in economics

\section{METHODS}

The data used in this study is secondary data obtained from the Central Bureau of Statistics. To see the overall, data is taken in 34 provinces in Indonesia during the period 2015 - 2017 and were subsequently converted to panel data. The analytical approach used in this study is a quantitative and descriptive approach. The spatial approach used is Klassen typology analysis and quantitative approach used the panel Granger causality models.

\section{Klassen's typology approach}

Klassen Typology Approach used to see the conditions of economic growth, poverty, and stunting by mapping the regions that require priority in the handling of stunting. The Mapping used average rate of poverty, average economic growth and average index of stunting from 2015-2017. The region is classified into the high rate of poverty and stunting, and regions with high economic growth and high stunting become a priority for governments. The following is typology Klassen used.

Table 1. Klassen's typology between stunting and poverty

\begin{tabular}{lcc}
\hline \multirow{2}{*}{ Stunting $($ STUN) } & \multicolumn{2}{c}{ Percentage of poverty rate (POV) } \\
\cline { 2 - 3 } & POVi $>$ POV & POVi $<$ POV \\
\hline STUNi $>$ STUN & Priority I & Priority II \\
STUNi $<$ STUN & Priority III & Priority IV \\
\hline
\end{tabular}

Table 2. Klassen's typology between stunting and economic growth

\begin{tabular}{ccc}
\hline \multirow{2}{*}{ Stunting $($ STUN) } & \multicolumn{2}{c}{ Percentage of economic growth $($ EG) } \\
\cline { 2 - 3 } & EGi $>$ EG & EGi $<$ EG \\
\hline STUNi $>$ STUN & Priority I & Priority II \\
STUNi $<$ STUN & Priority III & Priority IV \\
\hline
\end{tabular}

Where: STUNi is the amount of stunting in the province to $i$; STUN is the average number of stunting throughout the province; EGi is a percentage of provincial economic growth to $\mathrm{i}$; POVi is the percentage of poor provinces to $\mathrm{i}$; and POV is the average percentage of poor people across the province; and EG is the average percentage of economic growth throughout the province.

\section{Vector error correction model approach}

There are several steps before further estimating vector error correction model (VECM), we must ensure that the variables in the VEC model equation are stationary (not 
containing unit-root), then, we do find out the optimum lag in the model, and the last conducting Johansen's cointegration testing. Vector error correction model is the development of a VAR model for time series that is not stationary and has one or more cointegration relationships. The dynamic behavior of VECM can be seen through the response of each dependent variable to shocks to that variable and to other dependent variables. There are two approaches to be able to see the characteristics of the VECM, namely through the impulse response function and variance decomposition. The VECM model has one equation for each variable (as the dependent variable). VECM is characterized by the inclusion of an error correction term (ECT) element in the model. The general form of the VECM with lag length (p-1) is as follows:

$$
\begin{aligned}
& \Delta E G_{i, t}=\alpha_{1}+\beta_{1} \Delta E G_{i, t-1}+\gamma_{1} \Delta P O V_{i, t-1}+\delta_{1} \Delta S T U N_{i, t-1}+E C T_{i, t-1}+\varepsilon_{1 i, t} \\
& \triangle P O V_{i, t}=\alpha_{2}+\beta_{2} \Delta E G_{i, t-1}+\gamma_{2} \Delta P O V_{i, t-1}+\delta_{2} \Delta S T U N_{i, t-1}+E C T_{i, t-1}+\varepsilon_{2 i, t} \\
& \Delta S T U N_{i, t}=\alpha_{3}+\beta_{3} \Delta E G_{i, t-1}+\gamma_{3} \Delta P O V_{i, t-1}+\delta_{3} \Delta S T U N_{i, t-1}+E C T_{i, t-1}+\varepsilon_{3 i, t}
\end{aligned}
$$

Where: EG is economic growth; POV is the level of poverty; STUN is the prevalence of stunting; $i$ is a cross-section of each region; $t$ is a time-series data; $\alpha, \beta, \gamma, \delta$ are the coefficients in the model equation; and ECT is an error obtained from the model equation between EG, POV, and STUN in the one lag and also called the error correction term.

After getting the best VEC model, next, analyze the impulse response function to be able to interpret the VECM equation. The impulse response function describes the rate of shock from one variable to another at a certain time span, so that it can be seen the length of influence of the shock of a variable on another variable until the effect disappears or returns to the balance point. Furthermore, we analyze Variance decomposition or also called forecast error variance decomposition is a tool in the VECM equation to measure the estimated variance error of a variable that is how much the ability of one variable to provide an explanation for other variables or the variable itself. By using the VECM approach, it can be seen the proportion of the impact of changes on a variable if it experiences shock or changes to the variable itself in a period.

\section{RESULTS AND DISCUSSION}

The average rate of economic growth in Indonesia during the years 2015-2017 is at 5.44 percent. When viewed from the distribution of total GDP of each region to total GDP, it is dominated by the Province on the island of Java and Sumatra, for example the distribution of the GDP total Jakarta Provincial of the total GDP is at 16.50 percent, at 15 percent of East Java, West Java at 13.60 percent, at 9.1 percent of Central Java, North Sumatra and Riau 4.9 percent to 4.9 percent. Figure 2 shows that the spatial distribution of the high economic growth rate in Indonesia is located on the island of Kalimantan and Sulawesi. Provinces that have the highest economic growth in 2017 was North Maluku province at 7.67 percent, South Sulawesi much as 7.23 percent, and the Middle Selawesi at 7.14 percent. Meanwhile, over the last 5 years the highest average growth rate is in the province of Central Sulawesi with 10.87 percent, West Nusa Tenggara by 9.23 percent and at 7.28 South Sulawesi. Papua and Central Kalimantan each at 7.04 and 6.70 percent. 


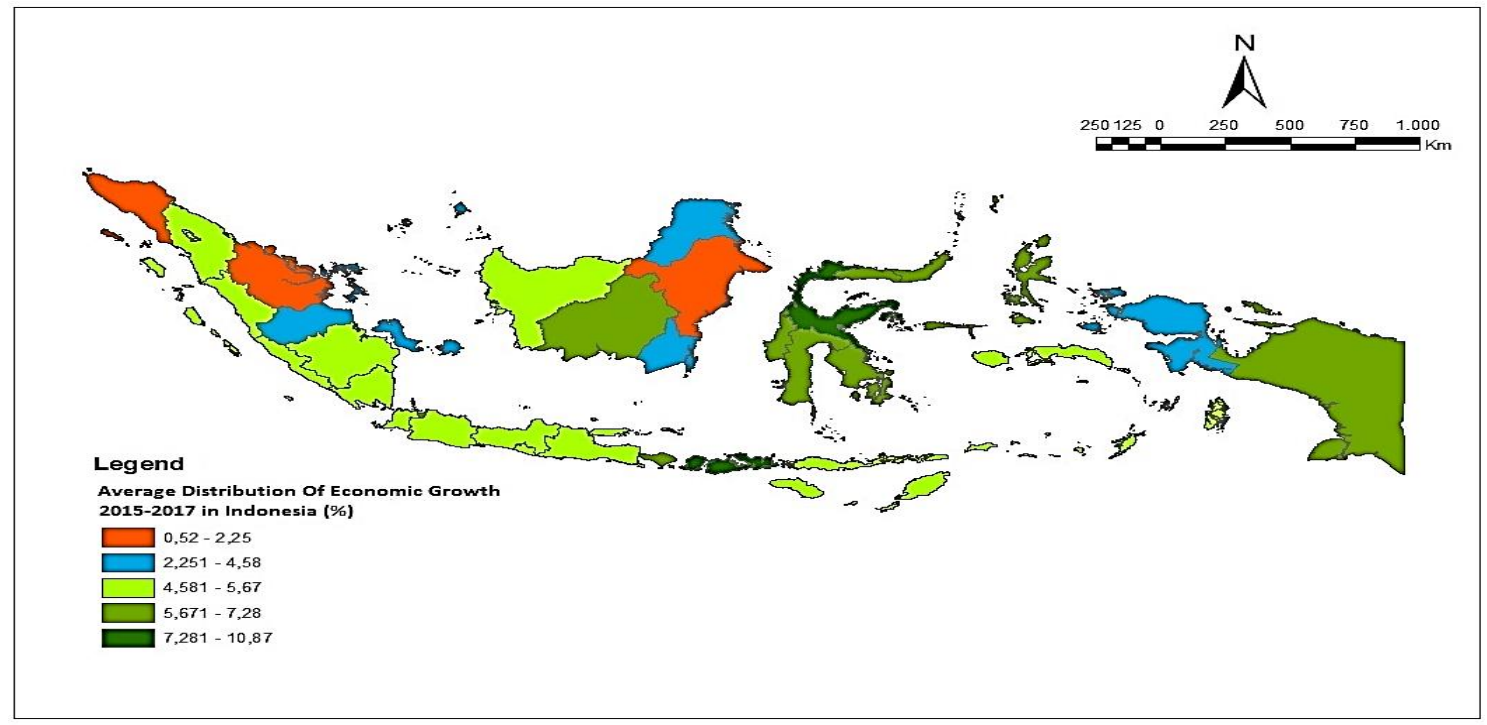

Figure 2. Distribution of economic growth average in Indonesia (\%), 2015-2017 Source: Authors calculation using ArcGIS 10.3, 2019

However, when viewed from the distribution of the total GDP, the GDP contribution of the Province on the island of Java and Sumatra are still relatively larger than the island of Borneo and Sulawesi. This is related to the income disparity between regions in Indonesia are still relatively high, so it can have an impact on the increasing levels of poverty in Indonesia.

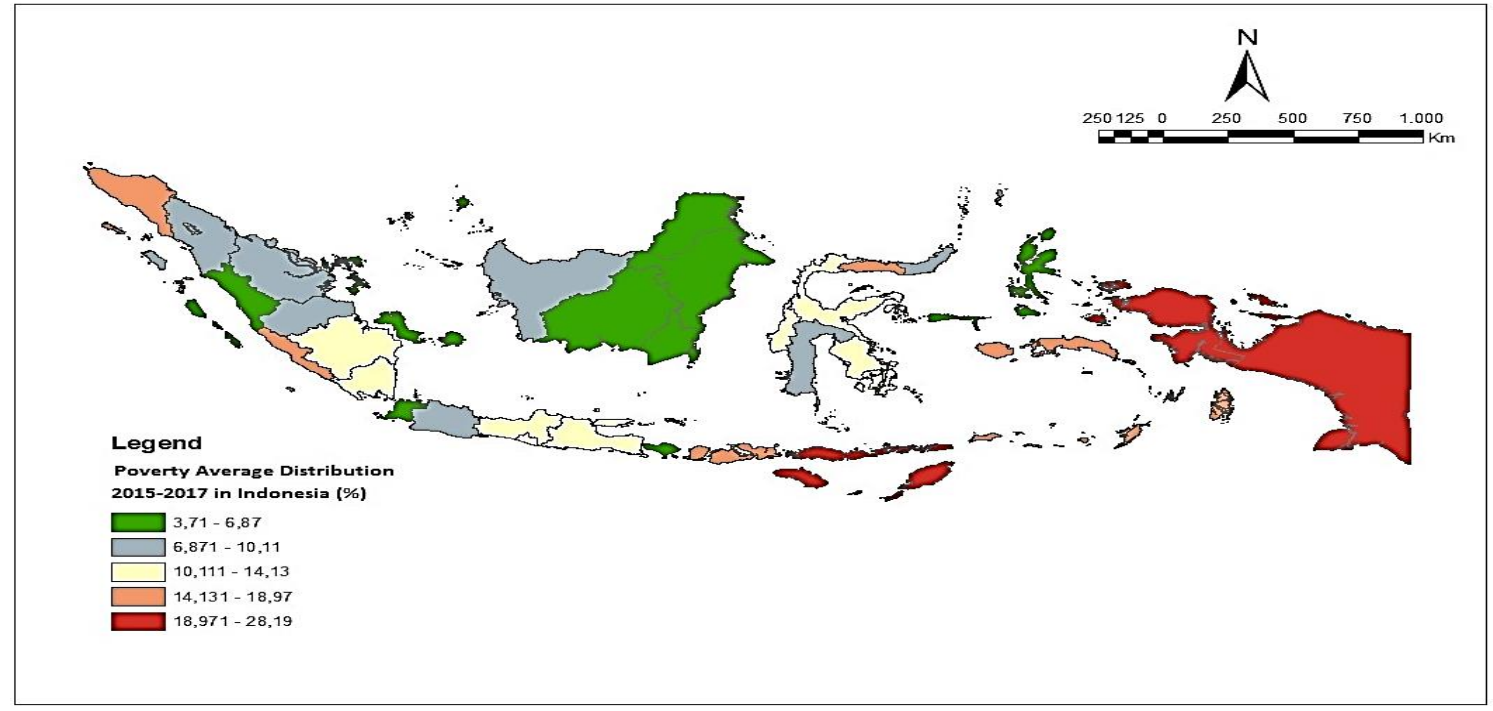

Figure 3. Distribution of poverty rate average in Indonesia (\%), 2015-2017

Source: Authors calculation using ArcGIS 10.3, 2019

Other than that, the average poverty rate in Indonesia during the years 2015-2017 is at 10.65 percent. Spatially shows that areas with relatively high levels of poverty are suffered by the provinces of Maluku, North Maluku, West Papua and Papua with an average poverty rate above 16 percent. It is associated with imbalance relatively high population growth, as well as lack of infrastructure related to education, health and welfare of the community. Meanwhile, regions with relatively low poverty rates are in the province of West Kalimantan, Central Kalimantan, South Kalimantan, East Kalimantan and North Borneo with an average of 6 percent. 


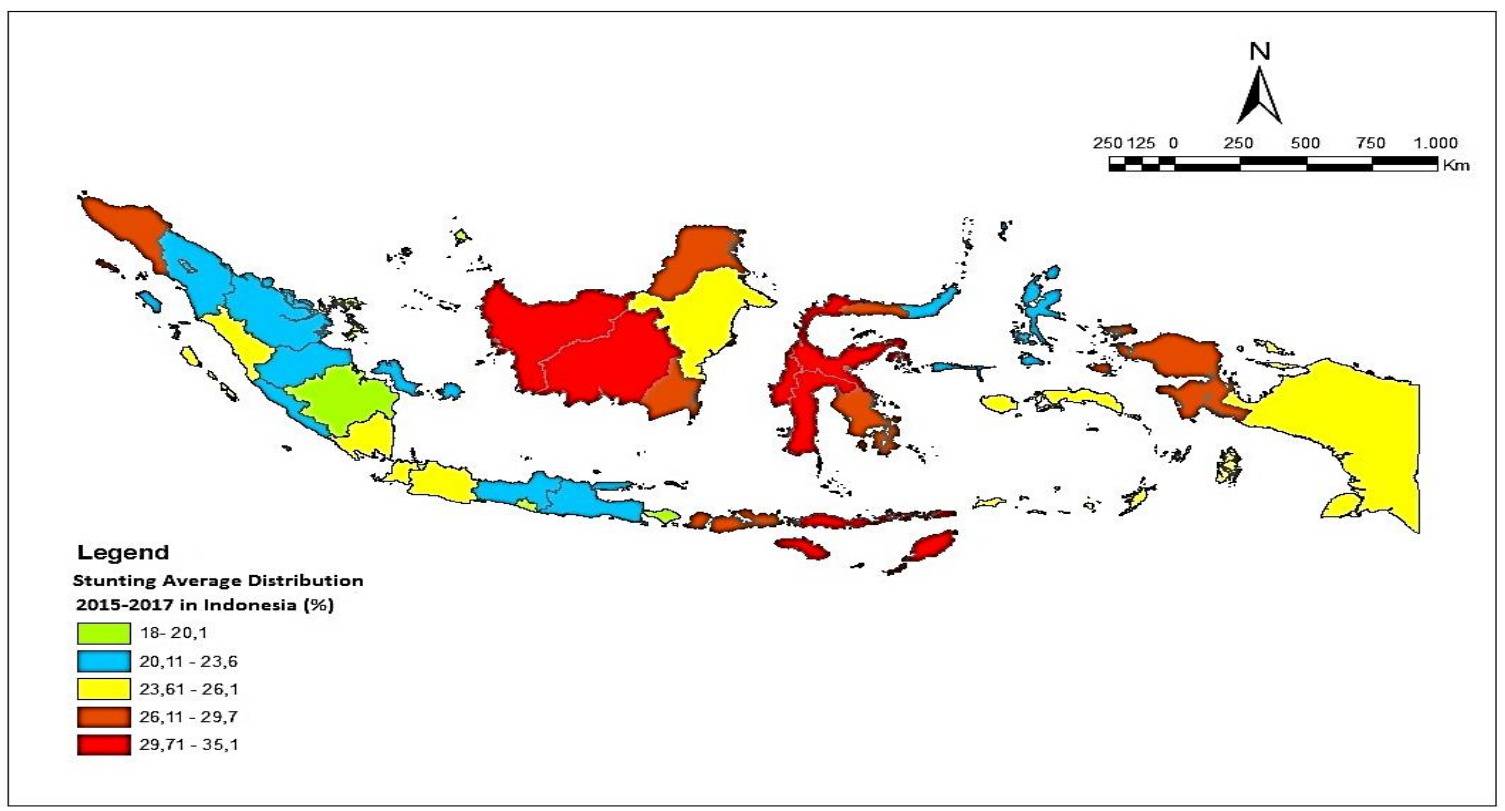

Figure 4. Distribution of stunting average in Indonesia (\%) 2015-2017 Source: Authors calculation using ArcGIS 10.3, 2019

Figure 4 shows that the depth and scope of the problem of malnutrition in 20152017 is the stunting rate that widespread in Indonesia which rated between 18 percent to more than 35 percent. When viewed by the island, the low rate of stunting which reached between $18-20.10$ percent are in the province of Riau Islands, South Sumatra, Jakarta, Yogyakarta and Bali. Relatively high stunting rate areas that reach between $29.71-35.10$ percent are in the province of East Nusa Tenggara, West Nusa Tenggara, West Kalimantan, Central Kalimantan, Central Sulawesi, Southeast Sulawesi, South Sulawesi, West Sulawesi and Gorontalo. This is related to the low intake of nutrition in the first 1,000 days of life, from fetus to baby age two. In addition, this condition also caused bt the relatively lack of sanitation facilities, access to clean water, and a lack of environmental cleanliness. Less intact hygiene conditions make the body should work extra to fight against sources of diseases that inhabit the absorption of nutrients. Study that have been done by Adewara. (2011) showed that the quality of clean drinking water has a positive relationship with a reduction in the incidence of diarrhea and death in children.

Furthermore, based on the result of the typology mapping of the region between stunting and economic growth which is divided into four quadrants, it is showed that the first quadrant are inhabited with the province of West Sulawesi, East Nusa Tenggara, Central Sulawesi, Southeast Sulawesi, West Nusa Tenggara, Gorontalo, Maluku and Central Kalimantan with average economic growth and stunting above the national average. This indicates that the economic growth may boost stunting faster. Therefore, the central and local governments should improve programs and policies that promote inclusive economic growth, and to improve the program and policies to prevent stunting. In other words, the province that inhabited the first quadrant is a top priority in the prevention of stunting programs and policies. 


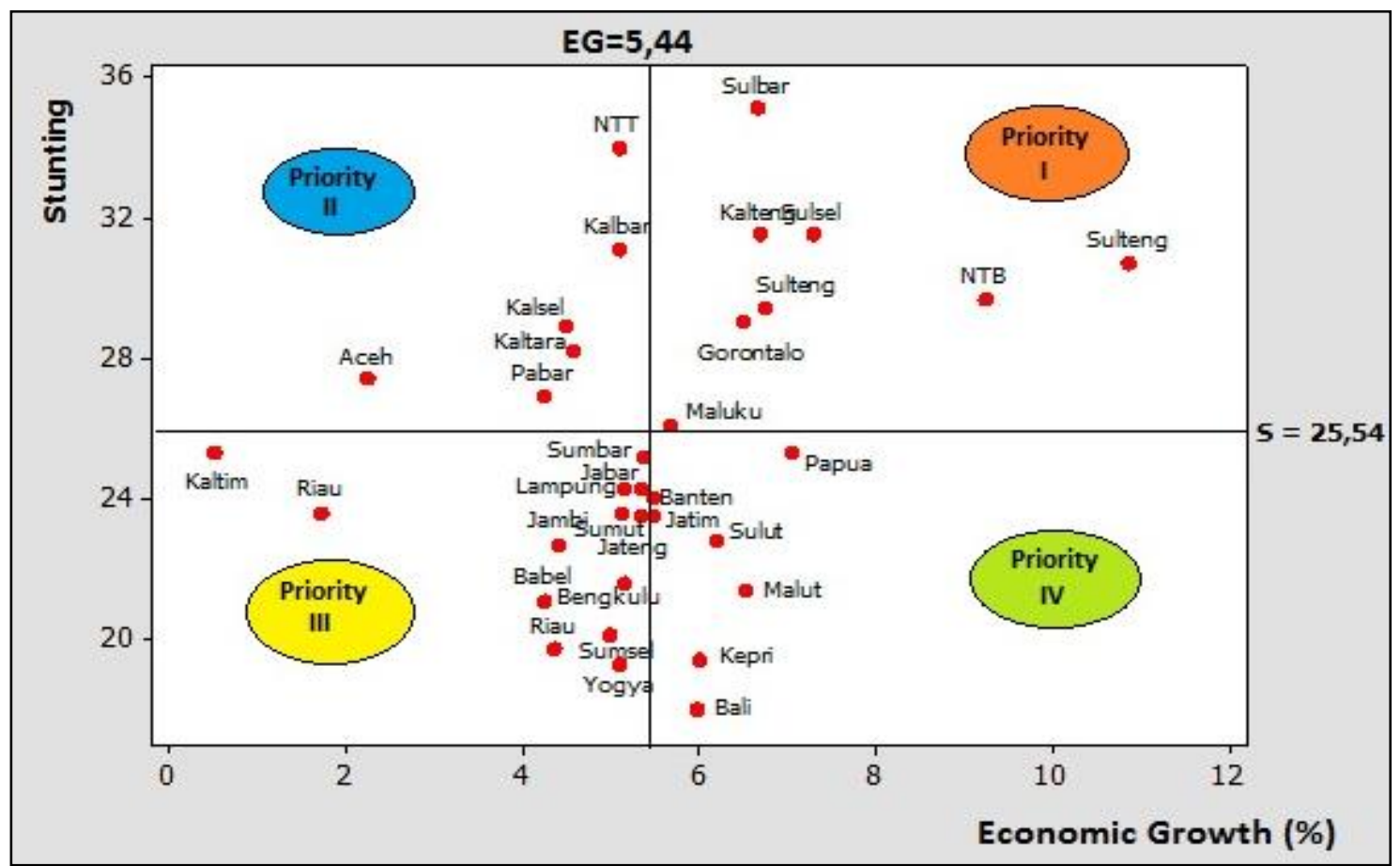

Figure 5. Typology of economic growth and stunting in Indonesia

Source: Authors calculation, 2019

Then, provinces inhabited Quadrant II are the province of West Kalimantan, South Kalimantan, West Kalimantan, West Papua, Aceh and North Borneo. The category of regions in Quadrant II are the region with economic growth below average, and the condition of stunting above average national. Therefore, efforts need to be undertaken by central and local government in the future is increasing effectiveness and efficiency of programs and policies in the prevention of stunting, and simultaneously encourage the acceleration of economic growth in some of the leading sectors such as industry, mining and agriculture.

In addition, the province inhabited Quadrant III are East Kalimantan Province, West Sumatra, West Java, Riau, North Sumatra, Lampung, Jambi, Bangka Belitung, Central Java, Bengkulu, South Sumatra and Yogyakarta. A category in Quadrant III is the region with an average economic growth and stunting below the national average. Therefore, the central and local governments need to work harder in improving programs and policies to encourage faster, inclusive, and sustainable economic growth, as well as improving and optimizing programs and policies to encourage a decrease of stunting.

While the area located in Quadrant IV are Papua Province, Banten, East Java, North Sulawesi, North Maluku, Riau Islands and Bali. This area shows the average conditions of economic growth above the national average, but the cases of stunting is above the national average. This indicates that the relatively high economic growth has not been an impact on the decrease the cases of stunting. Therefore, the central and local governments need to increase programs and policies in encouraging the development of the leading sectors such as agriculture and plantation sectors, as well as the industrial sector, especially domestic industry, so that economic growth can be run in inclusive and sustainable condition. In addition, the government needs to concentrate on improving programs and policies that have target in reducing stunting.

The results of the typology can be interpreted that human resources as economically potential has high productivity value. Thus, if the prevalence of stunting continued to increase, 
the perceived economic potential is also nationally high. Meanwhile, the relatively high economic growth does not have impact to the reduction of stunting, but does have an impact on increasing the income inequality which directly results in widespread poverty in Indonesia. Furthermore, we performed mapping with typology between stunting and poverty. Figure 5 shows that some regions, especially in Eastern Indonesia high poverty and stunting result were obtained, which strengthens the argument that stunting is very much linked with poverty.

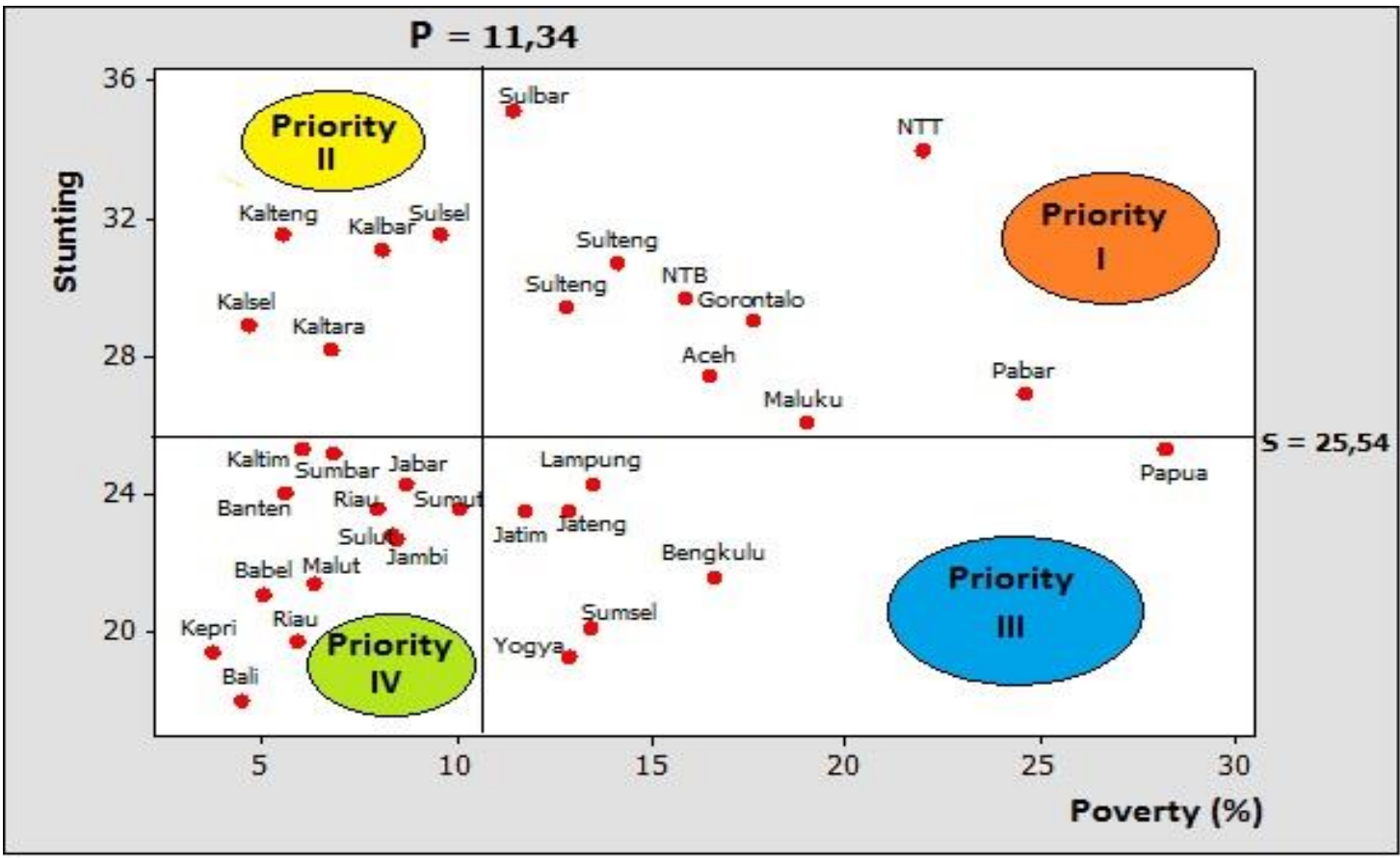

Figure 6. Typology of poverty and stunting in Indonesia Source: Authors calculation, 2019

Based on Figure 6 show typology of regions contained in quadrant I, namely the provinces of West Sulawesi, East Nusa Tenggara, Central Sulawesi, South Sulawesi, West Nusa Tenggara, East Nusa Tenggara, Gorontalo, Maluku, Aceh and West Papua, have growth and stunting rate average above the national average. This means that poverty that occurs can encourage increased rate of stunting. Therefore, the central and regional governments need to improve programs and policies related to reducing stunting and poverty optimally.

The area included in quadrant II consists of the provinces of West Kalimantan, South Kalimantan, Central Kalimantan, South Sulawesi and North Kalimantan, with a category of regions with a condition of poverty level below the national average, but has a stunting level above the national average. Therefore, the central and regional governments need to improve programs and policies related to poverty reduction and stunting optimally.

Further, the area contained in quadrant III consists of the provinces of Lampung, East Java, Central Java, Bengkulu, South Sumatra, Papua and Yogyakarta. These regions have conditions of poverty and stunting below the national average. Poverty reduction and stunting are relatively better in the area, so that the central and regional governments must play a role in improving programs and policies appropriately to encourage poverty and stunting reduction. Therefore, the role of government must be more optimal and targeted, so that poverty reduction and stunting can be relatively well addressed.

Meanwhile, the area contained in quadrant IV consists of the provinces of Banten, 
West Java, West Sumatra, North Sumatra, Jambi North Sulawesi, North Maluku, Riau Islands, Bangka Belitung, East Kalimantan and Bali. These regions have an average poverty rate that is relatively higher than the national average, but the stunting level is below the national average. This indicates that the programs and policies in stunting prevention are relatively well implemented. Nevertheless, the central and regional governments need to be more optimal in improving programs and policies related to poverty reduction such as increasing human resource capacity with education and training, health quality, and basic infrastructure development equally.

We present the testing phase which consists of the unit root test, optimal lag length, Johansen's cointegration, Granger causality model, impulse response function, and variance decompotition. The first, stationary testing data at the level stage is done by using the Hadri unit root test. The test results show that economic growth, poverty, and stunting is stationary at a significant level at 5 percent. The test results on the three variables level stage are shown in Table 3.

Table 3. The unit root test

\begin{tabular}{|c|c|c|c|}
\hline Variable & Hadri Z-Statistic & Prob. & Summary \\
\hline EG & $\begin{array}{l}6.00099 \\
8.52935\end{array}$ & 0.0000 & *Stationary \\
\hline POV & $\begin{array}{l}6.13287 \\
7.14118\end{array}$ & 0.0000 & *Stationary \\
\hline STUN & $\begin{array}{l}5.90344 \\
6.34963\end{array}$ & 0.0000 & *Stationary \\
\hline
\end{tabular}

Note: *Significant level at stationary $1 \%$

The next, in Table 4 shows the lag length is used to determine the dynamics and efficiency of the model. This determination is important to know the optimal lag used in the model equation of this study.

Tabel 4. The Lag length optimum

\begin{tabular}{ccccccc}
\hline Lag & LogL & LR & FPE & AIC & SC & HQ \\
\hline 0 & -556.4986 & NA & 2813.588 & 16.45584 & 16.55376 & 16.49464 \\
1 & -337.1062 & $412.9738^{*}$ & $5.781177^{*}$ & $10.26783^{*}$ & $10.65951^{*}$ & $10.42303^{*}$ \\
\hline
\end{tabular}

* indicates lag order selected by the criterion

LR: sequential modified LR test statistic (each test at $5 \%$ level)

FPE: Final prediction error

AIC: Akaike information criterion

SC: Schwarz information criterion

HQ: Hannan-Quinn information criterion

The optimal lag test results show that lag 1 is the most optimal lag due to the smallest Prediction Error (FPE), Akaike Information Criterion (AIC), Schwarz Information Criterion (SC) and Hannan-Quinn Information (HQ). This means that the optimal effect of variables on other variables occurs within the time horizon of 1 period.

Further, this test is to determine the long-term balance and the similarity of movement and stability of relationships between variables. The cointegration test in this study uses the Johansen Fisher panel cointegration test. An equation is said to be cointegrated if the probability value produced by the provision if the trace value is greater than the critical value so that there is cointegration between variables. 
Table 5. Johansen cointegration test

\begin{tabular}{lcccc}
\hline $\begin{array}{c}\text { Hypothesized } \\
\text { No. of CE(s) }\end{array}$ & Eigenvalue & $\begin{array}{c}\text { Trace } \\
\text { Statistic }\end{array}$ & $\begin{array}{c}0.05 \\
\text { Critical Value }\end{array}$ & Prob.** \\
\hline $\mathrm{r}=0$ & 0.760297 & 62.11253 & 29.79707 & 0.0000 \\
$\mathrm{r} \leq 1$ & 0.328397 & 13.54843 & 15.49471 & 0.0962 \\
$\mathrm{r} \leq 2$ & 0.000394 & 0.013415 & 3.841466 & 0.9076 \\
\hline Hypothesized & Eigenvalue & Max-Eigen & 0.05 & \multirow{2}{*}{ Prob. ${ }^{* *}$} \\
No. of CE(s) & Statistic & Critical Value & \\
\hline $\mathrm{r}=0$ & 0.760297 & 48.56411 & 21.13162 & 0.0000 \\
$\mathrm{r} \leq 1$ & 0.328397 & 13.53501 & 14.26460 & 0.0649 \\
$\mathrm{r} \leq 2$ & 0.000394 & 0.013415 & 3.841466 & 0.9076 \\
\hline
\end{tabular}

Trace and Max-eigenvalue test indicates 1 cointegrating eqn(s) at the 0.05 level

* denotes rejection of the hypothesis at the 0.05 level

**MacKinnon-Haug-Michelis (1999) p-values

Based on Table 5 shows that the value of Trace and Max-Eigen statistics is greater than the critical value of 5 percent, it can be concluded that statistically the null hypothesis is rejected, which means that there are a number of vectors in the cointegrated model. In other words, cointegration is found in the equation model. This finding indicates that in the long run the three variables have a relationship with each other. To find out more about the relationship between economic growth, poverty rate, and stunting prevalence, an estimation of the Granger causality model will be conducted.

Testing the classic assumptions in the model equation in Table 6 shows that from the results of testing the assumption of heteroscedasticity with the Breusch-PaganGodfrey approach get chi-square value in the amount of 82.84751 with a probability of 0.5151 , these results accept the null hypothesis, which means that there is no symptoms are heteroscedasticity in the equation model. Besides that, the normality assumption testing on each variable in the model equation indicated that the data distribution of each variable is normally distributed.

Table 6. Estimation result of vector error correction model

Short-run coefficient

\begin{tabular}{lccc}
\hline \multirow{2}{*}{ ECT: } & \multicolumn{3}{c}{ Dependent Variable } \\
\cline { 2 - 4 }$\Delta \mathrm{EG}$ & $\Delta(\mathbf{E G})$ & $\Delta(\mathbf{P O V})$ & $\Delta(\mathbf{S T U N})$ \\
\multirow{2}{*}{$\Delta \mathrm{POV}$} & - & 0.47801 & 0.43389 \\
& 1.25979 & $(0.4893)$ & $(0.5101)$ \\
\multirow{2}{*}{$\mathrm{STUN}$} & $(0.2617)$ & - & 0.04629 \\
& 1.43993 & 1.92977 & $(0.8296)$ \\
& $(0.2302)$ & $(0.1648)$ & - \\
\hline
\end{tabular}

Long-run coefficient

\begin{tabular}{lccc} 
ECT: & $0.11507 * * *$ & $0.04593 * * *$ & -0.07406 \\
Summary: & {$[4.6548]$} & {$[5.2131]$} & {$[-1.0357]$} \\
\hline Obs & & & \\
$\mathrm{R}^{2}$ & 68 & 68 & 68 \\
Adj. $\mathrm{R}^{2}$ & 0.65073 & 0.50454 & 0.10460 \\
F-stat & 0.60255 & 0.43620 & -0.01889 \\
\hline
\end{tabular}

\section{Diagnostic test}

Jarque-Bera

$3.007720(0.8079)$

Breusch-Pagan-Godfrey

Note: Level of siginificant $* * * 1 \%, * * 5 \%, * 10 \%$

Figure in [ ] is t-test and ( ) is probability value. 
Based on the estimation results of the VEC model in the short-term presented in Table 6 shows that there is no evidence of a causal relationship between economic growth, poverty rates, and stunting prevalence. This finding indicates that in the short term, the relationship between these variables is relatively unpredictable. This also proves that in order to reduce poverty and the stunting prevalence cannot be resolved in the short term, there needs to be an inclusive and sustainable policy to overcome these problems. The implications of these findings indicate that the problems of economic growth, poverty rates, and stunting prevalence are relatively insoluble in the short term. Inclusive and sustainable policies are needed to overcome these problems.

Based on the results of the error correction coefficient in the long-run economic growth model (EG) equation presented in Table 6 shows that there is a significant result in the error correction coefficient (ECT) of 0.11507 at a significance level of 1 percent which means that there is evidence of unidirectional causality flowing from poverty rates and stunting prevalence to economic growth in the long run. The findings reveal that whenever there is a shock in the system, the poverty rate and stunting prevalence can make short-term adjustments to restore the long-term balance in the amount of 0.11507 percent. The finding indicates that poverty rates and stunting prevalence have a direct impact on economic growth. In many studies show that poverty rates and stunting prevalence can have a negative impact on economic growth. This was also explained in a study conducted by Harttgen, Klasen, \& Vollmer (2013); Vollmer et al. (2014); Mary (2018) and Mcgovern, Krishna, Aguayo, \& Subramanian (2017).

Likewise, the poverty model equation shows a significant result in the error correction coefficient of 0.04593 at a significance level of 1 percent, which means that there is evidence of unidirectional causality flowing from economic growth and stunting prevalence to poverty rate in the long-run. The finding reveals that whenever there are shocks in the system, economic growth and stunting prevalence can make short-term adjustments to restore the long-term balance of 0.0455 percent. These findings indicate that economic growth and stunting prevalence have a direct influence on poverty levels. The implication of this finding indicates that economic growth in each region can relatively cause poverty rates. In many cases, economic growth can reduce poverty levels if the welfare level is more evenly distributed. On the other hand, economic growth can actually increase poverty, this is related to the relatively large income inequality occurs between urban and rural regions. In addition, the increasing number of malnutrition cases indicates that there is an inability of individuals in spending terms for nutritional food consumption needs. This was also explained in a study conducted by Hassan, Zaman, \& Gul (2015); Ncube, Anyanwu, \& Hausken (2013); and Niyimbanira (2017).

Meanwhile, the stunting model equation does not show evidence of significant results on the error correction coefficient, which means that there is no evidence of causality flowing from economic growth and poverty to the prevalence of stunting in the long run. These findings indicate that economic growth and poverty rates don't have a direct influence on stunting prevalence. The economic growth in each region in Indonesia has not directly affected the reduction in stunting prevalence, this is related to economic growth in Indonesia which is relatively uneven. In addition, the level of awareness of the poor population in consuming nutritious food is still relatively low, so reducing the number of stunting cases is still relatively difficult to solve. Therefore, there is a need for inclusive and sustainable policies to address the problem of stunting prevalence in Indonesia. This finding is relatively different from the results of the study Harttgen, Klasen, \& Vollmer (2013) and Vollmer et al. (2014) which found evidence that economic 
growth and poverty rates can increase stunting prevalence in developing countries. On the other hand, this finding contrasts with the results of the study Mary (2018) and Mcgovern, Krishna, Aguayo, \& Subramanian (2017) which found evidence that economic growth can reduce the prevalence of stunting in developing countries.

\section{Impulse response function}

The results of the impulse response function presented in Figure 7 provide information on the impact factor of the shock on one variable against the variable itself and other variables. In addition, the response function is to predict the impact of the relationship between variables in the long run. The response of stunting prevalence to poverty levels that tend to have a negative impact starts from the 3 to 10 period, this indicates that if there is a shock to the standard deviation of one of the poverty levels, then, the stunting prevalence tends to react negatively or decrease. Furthermore, the stunting prevalence response to shocks from economic growth tends to increase in the 3 to 9 periods, this indicates that if shocks by one standard deviation of economic growth, then stunting prevalence tends to react positively or increase.

The response of poverty rate to shocks from the stunting prevalence in the 1 to 2 periods tends to be negative, but in the next period up to the 10 period is relatively increased, this indicates that if there are shocks by one standard deviation of the poverty rates, then the stunting prevalence of reacts positively or relatively increases. Then the response of the poverty level to shocks from economic growth tends to be negative and increase in period 1 to 10 , this indicates that if shocks occur by one standard deviation of economic growth, then stunting prevalence tends to react negatively.

Response to Cholesky One S.D. (d.f. adjusted) Innovations

Response of STUN to POV
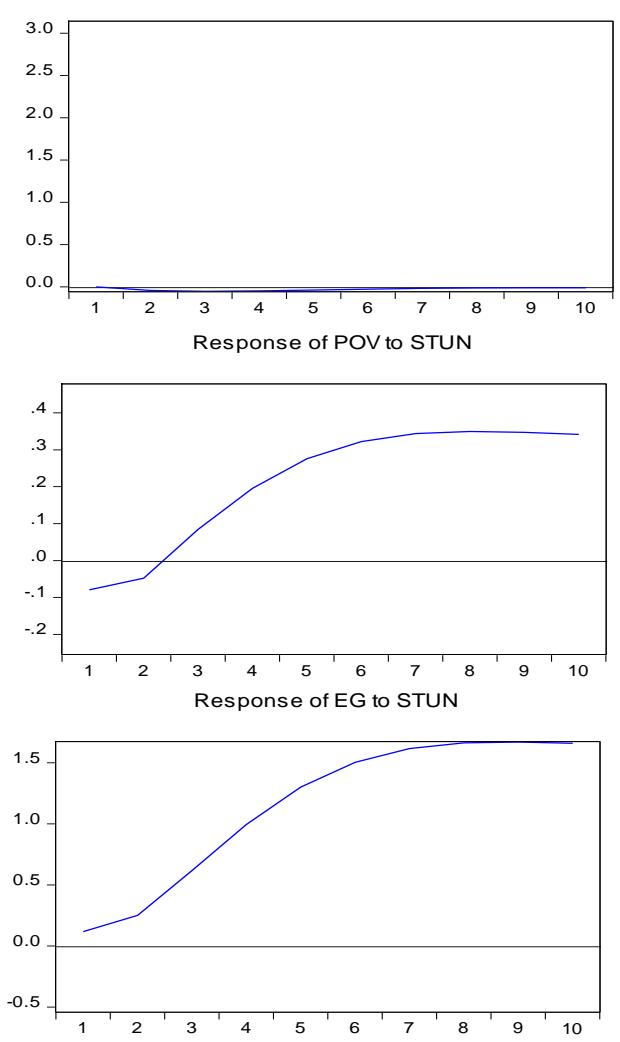

Response of STUN to EG
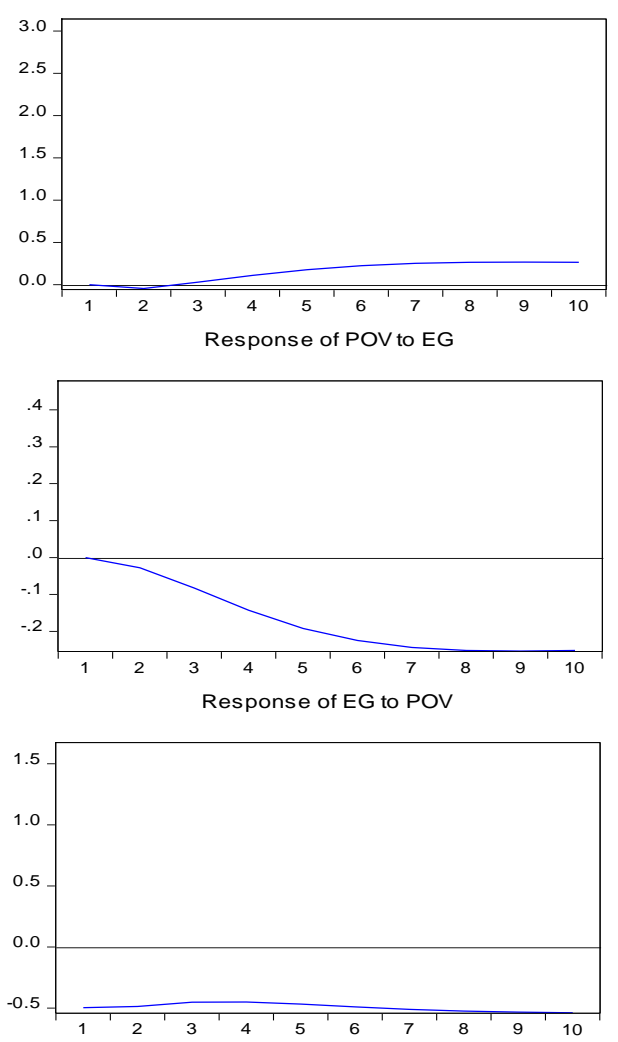

Figure 7. Impulse response function 
Meanwhile, the response of economic growth to shocks from the stunting prevalence in the 1 to 10 periods tends to react positively or increase, this indicates that if shocks occur at a standard deviation from the stunting prevalence, then economic growth tends to react positively to stunting prevalence. Furthermore, the response of economic growth to shocks from the poverty rates in the 4 to 10 periods tends to react negatively, this indicates that if shocks occur at a standard deviation from the poverty level, then economic growth tends to react negatively.

\section{Variance decompotition}

Table 7 shows that in the period 2 horizon, the predicted stunting of around 99.26 percent came from the stunting variable itself, the remaining 0.038 percent came from poverty and 0.359 percent from economic growth. Furthermore, in the prediction horizon of period 10, the stunting prediction of 98.95 percent comes from the stunting itself, and the remaining 0.959 percent comes from poverty and 0.1054 percent from economic growth.

Tabel 7. Variance decompotition

\begin{tabular}{|c|c|c|c|}
\hline \multicolumn{4}{|c|}{ Variance Decomposition of STUN: } \\
\hline Period & S.E. & POV & EG \\
\hline 1 & 3.680319 & 0.000000 & 0.000000 \\
\hline 2 & 4.383437 & 0.038026 & 0.035914 \\
\hline 3 & 4.648107 & 0.113319 & 0.064189 \\
\hline 4 & 4.756338 & 0.215501 & 0.081188 \\
\hline 5 & 4.802695 & 0.334604 & 0.090971 \\
\hline 6 & 4.823739 & 0.462172 & 0.096731 \\
\hline 7 & 4.834277 & 0.591890 & 0.100293 \\
\hline 8 & 4.840396 & 0.719513 & 0.102629 \\
\hline 9 & 4.844607 & 0.842441 & 0.104257 \\
\hline 10 & 4.847941 & 0.959235 & 0.105460 \\
\hline \multicolumn{4}{|c|}{ Variance Decomposition of POV: } \\
\hline Period & S.E. & STUN & EG \\
\hline 1 & 0.441958 & 0.019989 & 0.000000 \\
\hline 2 & 0.616607 & 0.061786 & 0.145621 \\
\hline 3 & 0.743751 & 0.099282 & 0.260737 \\
\hline 4 & 0.845072 & 0.130401 & 0.335199 \\
\hline 5 & 0.929348 & 0.155739 & 0.383623 \\
\hline 6 & 1.001247 & 0.176304 & 0.416523 \\
\hline 7 & 1.063624 & 0.193044 & 0.439958 \\
\hline 8 & 1.118388 & 0.206742 & 0.457359 \\
\hline 9 & 1.166894 & 0.218030 & 0.470730 \\
\hline 10 & 1.210151 & 0.227401 & 0.481292 \\
\hline \multicolumn{4}{|c|}{ Variance Decomposition of EG: } \\
\hline Period & S.E. & STUN & POV \\
\hline 1 & 1.368072 & 0.001004 & 1.624721 \\
\hline 2 & 1.433481 & 0.151630 & 1.610392 \\
\hline 3 & 1.440568 & 0.282558 & 1.605523 \\
\hline 4 & 1.441716 & 0.355481 & 1.603903 \\
\hline 5 & 1.442035 & 0.390106 & 1.603311 \\
\hline 6 & 1.442155 & 0.405487 & 1.603085 \\
\hline 7 & 1.442204 & 0.412115 & 1.603013 \\
\hline 8 & 1.442225 & 0.414927 & 1.603012 \\
\hline 9 & 1.442234 & 0.416109 & 1.603044 \\
\hline 10 & 1.442238 & 0.416601 & 1.603091 \\
\hline
\end{tabular}

Cholesky Ordering: STUN POV EG 
The poverty prediction for period 2 is around 99.79 percent sourced from the poverty variable itself, the remaining 0.61 percent comes from stunting and 0.146 percent from economic growth. Furthermore, in the period 10, predictions of poverty of 99.29 percent came from poverty itself, and the remaining 0.227 percent came from stunting and 0.481 percent from economic growth. Prediction of economic growth in period 2 around 98.23 percent comes from the economic growth variable itself, the rest of 0.151 percent comes from stunting and 1.61 percent poverty. Furthermore, in the prediction of periods 10 , the predicted economic growth of 98.23 percent comes from economic growth itself, and the remaining 0.416 percent comes from stunting and 1,603 percent from the poverty level.

\section{CONCLUSIONS AND RECOMMENDATIONS}

\section{Conclusions}

The conclusion from this study results is the priority handling of the problem of the high stunting prevalence focus in the islands of Sulawesi, Maluku, Kalimantan, Nusa Tenggara, and Papua. Furthermore, addressing the problem of economic growth slow focus in the Islands of Kalimantan and Sumatra. Meanwhile, the handling of high poverty levels focus on the islands of Sulawesi, Sumatra, Nusa Tenggara, Maluku, and Papua. On the other side of this study, we get evidence of unidirectional causality flowing from poverty rates and the stunting prevalence toward economic growth in the long-run. The contribution of the stunting case is more dominant to have an impact on slowing economic growth. We also find evidence of unidirectional causality flowing from economic growth and stunting to poverty levels in the long-run, the contribution of economic growth is relatively more dominant with an impact on reducing poverty levels. While there is no evidence of causality flowing from economic growth and poverty to stunting, we have also found that poverty rates have a relatively high contribution to the increase in stunting cases in Indonesia.

\section{Recommendations}

The implications of this finding shows that inclusive and sustainable policies or programs are needed to solve this problems since they are estimated to be caused by inequality of income and economic growth amongst regions. Things that should be prioritized are high growth and poverty, and also an inclusive economic increase to reduce growth rates by applying poverty alleviation programs. There are some limitations that have not been discussed until the unit is approved (for example in the level of district/city, sub-district, village) so future studies are recommended to make some updates in order to make them become more focused and on point.

\section{REFERENCES}

Adair, L. S., Fall, C. H., Osmond, C., Stein, A. D., Martorell, R., Ramirez-Zea, M., Sachdev, H.S., Dahly, D.L., Bas, I., Norris, S.A., Micklesfield, L., Hallal, P., \& Victora, C. G. (2013). Associations of linear growth and relative weight gain during early life with adult health and human capital in countries of low and middle income: findings from five birth cohort studies. Lancet, 382(9891), 525-534. https://doi.org/10.1016/S0140-6736(13)60103-8

Adeyeye, S. A. O., Adebayo-Oyetoro, A. O., \& Tiamiyu, H. K. (2017). Poverty and 
malnutrition in Africa: a conceptual analysis. Nutrition \& Food Science, 47(6), 754-764. https://doi.org/10.1108/NFS-02-2017-0027

Alderman, H., Haddad, L., \& Headey, D. D. (2014). Association between economic growth and early childhood nutrition. The Lancet, 2(9), e500.

Barker, D. J. P. (2007). Introduction: The Window of Opportunity. The Journal of Nutrition, 137, 1058-1059.

Beal, T., Tumilowicz, A., Sutrisna, A., Izwardy, D., \& Neufeld, L. M. (2018). A review of child stunting determinants in Indonesia. Maternal and Child Nutrition, 14(e12617), 1-10. https://doi.org/10.1111/mcn.12617

Crahay, P., Mitchell, A., Gomez, A., Israël, A. D., Salpeteur, C., Mattinen, H., Deret, H., Lapegue, J., Grosjean, L., Aissa, M.A., Brown, R., Swan, S.H., Pietzsch, S \& Dufour, C. (2010). The threats of climate change on undernutrition - a neglected issue that requires further analysis and urgent actions. SCN News, (38), 4-10.

Dewey, K. G., \& Begum, K. (2011). Long-term consequences of stunting in early life. Maternal \& Child Nutrition, 7(Suppl. 3), 5-18. https://doi.org/10.1111/j.17408709.2011.00349.x

Frimpong, J., Okoye, D., \& Pongou, R. (2016). Economic Growth, Health Care Reform, and Child Nutrition in Ghana. Journal of African Development 2016, 18(2), 4160.

Granger, C. W. J. (1969). Investigating Causal Relations by Econometric Models and Cross-spectral Methods. Econometrica, 37(3), 424-438. https://doi.org/10.2307/1912791. JSTOR 1912791

Harttgen, K., Klasen, S., \& Vollmer, S. (2013). Economic growth and child undernutrition in sub-Saharan Africa. Population and Development Review, 39, 397-412.

Hassan, S. A., Zaman, K., \& Gul, S. (2015). The Relationship between GrowthInequality-Poverty Triangle and Environmental Degradation: Unveiling the Reality. Arab Economics and Business Journal, 10(1), 57-71. https://doi.org/10.1016/j.aebj.2014.05.007

Jr Richard, H. A. (2004). Economic Growth, Inequality and Poverty: Estimating the Growth Elasticity of Poverty. World Development, 32(12), 1989-2014.

Kuada, J. (2014). Economic growth and poverty alleviation in Africa - linking hard and soft economics. African Journal of Economic and Management Studies, 5(1), 2-8. https://doi.org/10.1108/AJEMS-03-2014-0016

Lyakurwa, W. (2009). Prospects for economic governanc: resilient pro-poor growth. Foresight, 11(4), 66-81. https://doi.org/10.1108/14636680910982449

Martorell, R., Horta, B. L., Adair, L. S., Stein, A. D., Richter, L., Fall, C. H. D., Bhargava, S.K., Biswas, S.K.D., Perez, L., Barros, F. C. \& Victoria, C.G. (2010). Weight Gain in the First Two Years of Life Is an Important Predictor of Schooling Outcomes in Pooled Analyses from Five Birth Cohorts from. The Journal of Nutrition, 140(2), 348-354. https://doi.org/10.3945/jn.109.112300.(SES)

Mary, S. (2018). How Much Does Economic Growth Contribute to Child Stunting Reductions? Economies, 55(6), 1-18. https://doi.org/10.3390/economies6040055

Mcgovern, M. E, Krishna, A., Aguayo, V. M., \& Subramanian, S. V. (2017). A review of the evidence linking child stunting to economic outcomes. International Journal of Epidemiology, 46(4), 1171-1191. https://doi.org/10.1093/ije/dyx017 
Mcgovern, Mark E, Krishna, A., Aguayo, V. M., \& Subramanian, S. (2017). Social and Economic Determinants A review of the evidence linking child stunting to economic outcomes. International Journal of Epidemiology, (March), 1171-1191. https://doi.org/10.1093/ije/dyx017

Ncube, M., Anyanwu, J., \& Hausken, K. (2013). Inequality, Economic Growth, and Poverty in the Middle East and North Africa (MENA) (No. 195). Tunis, Tunisia.

Niyimbanira, F. (2017). Analysis of the Impact of Economic Growth on Income Inequality and Poverty in South Africa: The Case of Mpumalanga Province. International Journal of Economics and Financial Issues, 7(4), 254-261.

Ogundari, K., \& Aromolaran, A. (2017). Nutrition and economic growth in sub-Saharan Africa: a causality test using panel data. International Journal of Development Issues, 16(2), 174-189. https://doi.org/10.1108/IJDI-12-2016-0076

Onis, M. De, \& Branca, F. (2016). Childhood Stunting: A Global Perspective. Maternal \& Child Nutrition, 12(1), 12-26. https://doi.org/10.1111/mcn.12231

Pulok, M. H., Sabah, M. N.-U., \& Enemark, U. (2016). Socioeconomic inequalities of child malnutrition in Bangladesh. International Journal of Social Economics, 43(12), 1439-1459.

Rashad, A. S., \& Sharaf, M. F. (2018). Economic Growth and Child Malnutrition in Egypt: New Evidence from National Demographic and Health Survey. Social Indicators Research, 135(2), 769-795. https://doi.org/10.1007/s11205-0161515-y

Ruel, M. T., \& Alderman, H. (2013). Nutrition-sensitive interventions and programmes: How can they help to accelerate progress in improving maternal and child nutrition? The Lancet, 382, 536-51. https://doi.org/10.1016/S0140-6736(13)60843-0

Semba, R. ., \& Bloem, M. W. (2001). Nutrition and Health in Developing Countries. New Jersey: Humana Press.

Smith, L. C., \& Haddad, L. (2015). Reducing child undernutrition: past drivers and priorities for the post-MDG era. World Development, 68, 180-204. https://doi.org/10.1016/j.worlddev.2014.11.014

Titaley, C. R., Ariawan, I., Hapsari, D., Muasyaroh, A., \& Dibley, M. J. (2019). Determinants of the Stunting of Children Under Two Years Old in Indonesia: A Multilevel Analysis of the 2013 Indonesia Basic Health Survey. Nutrients, 11(1106), 1-13. https://doi.org/10.3390/nu11051106

Vilcins, D., Sly, P. D., \& Jagals, P. (2018). Environmental Risk Factors Associated with Child Stunting: A Systematic Review of the Literature. Annals of Global Health, 84(4), 551-562. https://doi.org/10.29024/aogh.2361

Vollmer, S., Harttgen, K., Subramanyam, M. A., Finlay, J., Klasen, S., \& Subramanian, S. V. (2014). Association between economic growth and early childhood undernutrition : evidence from 121 Demographic and Health Surveys from 36 lowincome and middle-income countries. The Lancet Global Health, 2(4), e225-e234. https://doi.org/10.1016/S2214-109X(14)70025-7

Vonaesch, P., Tondeur, L., Breurec, S., Bata, P., Nguyen, L.B.L, Frank, T., Farra, A., Rafai, C., Vernick, T., Gody, J.C., Gouandjika-Vasilache, I, Sansonetti, P. \& Vray, M. (2017). Factors associated with stunting in healthy children aged 5 years and less living in Bangui (RCA). PLoS ONE, 12(8), e0182363. 
https://doi.org/10.1371/journal. pone.0182363

World Health Organization. (2018). Levels and Trends in Child Malnutrition. United States. Retrieved from www.who.int/nutgrowthdb article distributed under the terms and conditions of the Creative Commons Attribution (CC BY) license (http://creativecommons.org/licenses/by/4.0/). 